\title{
Gorontalo
}

Journal of Government and Political Studies

Volume 4 - NO. 1 - April 2021

P-ISSN: 2614-2120 E-ISSN: 2614-2104

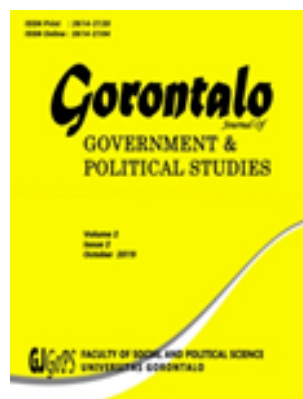

\section{Tinjauan Sikap dan Kebijakan Negara-Negara Terkait Pengungsi Timur Tengah: Peran Strategis Negara-Negara Mayoritas Muslim dalam Perspektif Islam}

\author{
Andi Darussalam, \\ Farahdiba Rahma Bachtiar, \\ Fakultas Usluhuddin, Filsafat dan Politik \\ Andi Zulfikar D \\ Fakultas Ekonomi dan Bisnis Islam \\ Universitas Islam Negeri Alauddin Makassar \\ J1. Sultan Alauddin No.63Kabupaten Gowa, Sulawesi Selatan \\ andidarussalamtajang@gmail.com
}

Received: 18th March 2021; Revised: 24th March 2021 ; Accepted: 26th March 2021 ;

\begin{abstract}
The issue of refugees is one of the crucial issues that is currently becoming a trending topic in the international world. This can be seen from the media headlines and the proliferation of refugee camps scattered in Indonesia's various places. It is necessary to have a comprehensive and collective policy towards handling refugees in a bilateral framework by each country. However, it is necessary to have multilateral policies by Muslim-majority countries to overcome the refugee problem. This research uses a qualitative method with a case study method, focuses explicitly on Muslim-majority countries. In contrast, the type of data used in this research is data through library research/literature review, namely reports of related institutions, journals, books, websites, UNHCR data, and the results of previous research related to refugee issues. This study indicates that the attitudes and policies adopted by Muslim-majority countries related to refugees originating from the Middle East, in terms of quantity (people), the majority of refugee recipients come from OIC countries, especially in Turkey, Pakistan, Iran, and Lebanon. There are policy strategies that Muslim-majority countries can undertake to address refugee problems, including establishing a Refugee Emergency Team to safely travel to certain countries, providing education and employment rights. Islamic teachings related to refugees' handling have been discussed in many verses, hadiths, and Islamic history. However, people in Muslim countries rarely mention and articulate 'hijrah' when dealing with refugees, so that awareness and improvement of the quality of handling refugees is needed.
\end{abstract}

Keywords: refugees; crisis; Islam; humanity

\section{ABSTRAK}

Isu pengungsi merupakan salah satu isu krusial yang sedang menjadi trending topic di dunia internasional. Hal ini terlihat dari headline media dan maraknya kamp pengungsian yang tersebar di berbagai tempat di Indonesia. Diperlukan kebijakan yang komprehensif dan kolektif terhadap penanganan pengungsi dalam kerangka bilateral oleh masing-masing negara, diperlukan adanya kebijakan multilateral oleh negara mayoritas muslim untuk mengatasi masalah pengungsi. Penelitian ini menggunakan 
metode kualitatif dengan metode studi kasus, berfokus secara eksplisit pada negaranegara mayoritas Muslim. Sedangkan jenis data yang digunakan dalam penelitian ini adalah data melalui studi pustaka/ literatur review yaitu laporan instansi terkait, jurnal, buku, website, data UNHCR, dan hasil penelitian sebelumnya terkait masalah pengungsi. Studi ini menunjukkan bahwa sikap dan kebijakan yang diadopsi oleh negara-negara mayoritas Muslim terkait pengungsi yang berasal dari Timur Tengah, secara kuantitas (orang), mayoritas penerima pengungsi berasal dari negara-negara OKI, khususnya di Turki, Pakistan, Iran, dan Libanon. Ada strategi kebijakan yang dapat dilakukan oleh negara-negara mayoritas Muslim untuk mengatasi masalah pengungsi, termasuk membentuk Tim Darurat Pengungsi untuk bepergian dengan aman ke negaranegara tertentu (penerima suaka), dan memberikan hak pendidikan serta pekerjaan. Ajaran Islam terkait penanganan pengungsi telah dibahas dalam banyak ayat, hadits, dan sejarah Islam. Namun masyarakat di negara muslim jarang sekali menyebut dan mengartikulasikan 'hijrah' ketika berhadapan dengan pengungsi, sehingga diperlukan kesadaran dan peningkatan kualitas penanganan pengungsi bagi umat Islam.

\section{Keywords: pengungsi; krisis; Islam; kemanusiaan}

\section{PENDAHULUAN}

Isu pengungsi merupakan salah satu isu krusial yang tengah menjadi trending topic di dunia internasional. Hal ini terlihat bukan hanya dari headline media namun juga tampak dari maraknya kamp pengungsi yang tersebar daerah-daerah di Indonesia. Situasi terkait pengungsi memang menjadi kian memburuk dalam lima dekade terakhir terutama oleh karena dampaknya tidak hanya bisa dirasakan secara regional namun juga global. Persoalan terkait pengungsi terutama yang berasal dari Timur Tengah pada dasarnya bukanlah menjadi hal baru karena telah dimulai sejak pecahnya perang Arab-Israel pada 1948 dan kemudian Perang Teluk pada terjadi pada 1990 yang menyebabkan korban mencapai 1,5 juta orang (Pinfari, 2009).

Meski demikian, konflik yang dimulai dari Tunisia pada Desember 2010 membawa efek domino bagi demokratisasi di kawasan Timur Tengah yang kemudian dikenal sebagai Arab Spring (Dunay, 2017), mengakibatkan melebarnya dampak sosial politik dan ekonomi yang diakibatkan dari situasi tersebut. Sekitar 250 ribu orang meninggal dan sekitar 11 juta manusia yang kehilangan tempat tinggal dan harus mengungsi (Amnesty International, 2016). Jumlah pengungsi dari Timur Tengah merupakan jumlah terbesar dibandingkan kawasan lain yakni sekitar 7 ribu dari 2,5 juta pengungsi yang terdata oleh United Nations High Commisioner for refugees (UNHCR) (The World Bank, 2018). Konflik tersebut juga diperparah akibat gerakan terrorisme yang lahir dari kelompok-kelompok bersenjata anti pemerintah selama perang dingin berlangsung di sekitar tahun 1990an seperti ISIS dan Jabhat al-Nusra, menjadikan negara-negara tersebut menjadi tidak stabil dan mencekam (Amnesty International, 2016).

Ketidakamanan kawasan yang terjadi akibat konflik dalam rentan waktu bersamaan menyebabkan pengungsi harus mencari opsi negara tujuan di luar negara-negara yang berada di wilayah Timur Tengah termasuk di dalamnya Asia Barat dan Afrika Utara. Negara-negara maju seperti Australia, Amerika Serikat dan Uni Eropa yang memang telah menjadi negara tujuan yang populer di era sebelumnya tetap menjadi tujuan utama pengungsi internasional. Hal ini menjadi wajar dikarenakan dari segi situasi dan kondisi baik ekonomi maupun sosial, negara maju yang kebanyakan negara barat menjadi tempat yang kondusif dan stabil untuk menetap dalam jangka panjang. 
Sayangnya, makin tingginya angka pengungsi tidak berbanding lurus dengan kesiapan negara-negara dan lembaga internasional terkait yakni UNHCR dalam menangani dampaknya. Akibatnya, penanganan terhadap pengungsi internasional tidak dilakukan sesuai standar karena baik negara tujuan maupun UNHCR kewalahan dalam membendung arus pengungsi yang masif. Data menyebutkan bahwa angka pengungsi internasional terus meningkat (UNHCR, 2019). Data terbaru menyebutkan bahwa saat ini ada 20,4 juta pengungsi yang tersebar di seluruh dunia. Namun, ini bukan menjadi sesuatu yang mengherankan. Oleh sebab, persoalan pengungsi esensinya tidak dapat diselesaikan oleh satu pihak semisal UNHCR semata. Dalam pembiayaan misalnya, untuk wilayah Indonesia sendiri, UNHCR hanya mampu membiayai sekitar 300 sampai 400 pengungsi yang tersebar dari seluruh Indonesia dari jumlah total 14 ribu jiwa (CNN Indonesia, 2019).

Salah satu persoalan yang paling subtantif dalam penanganan pengungsi adalah sulitnya aturan untuk masuk ke negara-negara tujuan yang pada umumnya merupakan negara-negara Barat. Massifnya jumlah pengungsi dalam beberapa tahun terakhir menjadi faktor pendorong bagi negara-negara Barat dalam membuat kebijakan yang tidak pro bahkan cendrung menutup pintu terhadap pengungsi (Amnesty International, 2015). Adanya tentangan atau sikap oposisi dari dalam negeri menjadi alasan utama. Akibatnya pemerintah negaranegara barat malah berangsur-angsur mengurangi bantuannya kepada lembaga internasional terkait semisal mundurnya Amerika Serikat dalam mendanai bantuan untuk Palestina dan Program UN Relief sejak 2018 (HRH Prince El Hassan bin Talal of Jordan, 2019).

Sikap negara-negara barat yang cenderung mundur terhadap penanganan pengungsi menjadi titik tolak bagi negara-negara mayoritas muslim untuk turun tangan dalam mengatasi krisis kemanusiaan yang terjadi. Selama ini, negaranegara muslim cenderung kurang pro aktif dalam membantu penanganan pengungsi internasional, adapun kebijakan atau program yang dilakukan biasanya bersifat terbatas. Padahal, fakta menunjukkan bahwa mayoritas dari pengungsi adalah umat muslim. Sehingga, penting bagi negara-negara berpenduduk muslim untuk berperan aktif dalam mengatasi persoalan pengungsi.

Oleh karena itu, diperlukan adanya kebijakan yang komprehensif dan kolektif terhadap penanganan pengungsi yang tidak hanya sepihak dan dilakukan dalam kerangka bilateral oleh masing-masing negara namun dibutuhkan adanya kebijakan multilateral oleh negara mayoritas muslim untuk secara bersama bergerak dalam mengatasi persoalan pengungsi. Dalam pandangan Islam, sesama muslim memiliki kewajiban untuk saling membantu. Selain itu, perempuan dan anak-anak merupakan pihak yang harus dilindungi. Hal ini sejalan dengan Konvensi Genewa 1951. Sehingga secara moral, negara mayoritas muslim memiliki peran sangat penting dalam membantu pengungsi tersebut. Berdasarkan hal tersebut, penelitian ini akan berfokus kepada kajian teoritis dan solusi praktis terhadap upaya penanganan pengungsi berdasarkan perspektif Islam.

Studi mengenai isu pengungsi termasuk di dalamnya kajian mengenai kebijakan dan perspektif Islam terkait isu tersebut telah banyak diteliti terutama seperti yang dikemukakan dalam bagian pendahuluan, pasca arus demokratisasi di Timur Tengah yang masif di tahun 2011. Hampir delapan 
tahun semenjak revolusi terjadi di Mesir, Suriah, Yaman dan beberapa negara arab lainnya, isu pengungsi terus menjadi bahan kajian interdisipliner yang banyak dikaji. Ini dikarenakan permasalahan pengungsi internasional tidak hanya soal krisis kemanusiaan dikarenakan isu yang multidimensi mencakup isu politik, ekonomi, agama dan budaya. Fokus dalam penelitian ini sendiri ditekankan pada persoalan kebijakan di level eksekutif atau pemerintahan. Oleh karena itu kajian terdahulu yang menjadi landasan dalam penelitian ini berfokus pada dua area kajian yakni kebijakan Indonesia dan negara mayoritas muslim terkait pengungsi serta perspektif Islam terkait pengungsi.

Studi sebelumnya yang membahas mengenai sikap dan kebijakan pengungsi internasional oleh negara-negara mayoritas muslim belum banyak diterbitkan. Studi yang dilakukan sebelumnya kebanyakan mengkaji isu pengungsi internasional dari paradigma negara bangsa seperti yang ditulis Breitman \& Kraut (1987) dan yang terbaru Hangartner et.al (2019). Meskipun kedua studi tersebut memberi kontribusi penting dalam menemukan solusi terhadap kebijakan negara-negara terhadap pengungsi yang cenderung menentang atau kontra, namun keduanya berfokus kepada dampak negatif yang bisa dibawa oleh pengungsi dan bagaimana hal tersebut memunculkan kebijakan anti pengungsi dan imigran.

Banyaknya studi mengenai pengungsi dari paradigma negara bangsa di satu sisi sejalan dengan tidak diimbanginya studi yang menggunakan perspektif Islam terkait pengungsi. Meskipun Adiputera dan Prabandari (2018:16) mengatakan bahwa diperlukan analisis yang hati-hati dalam mengkaji isu pengungsi dari perspektif agama, dengan menggunakan pendekatan secara umum, namun penelitian ini berargumen bahwa kajian mengenai pengungsi dalam perspektif agama khususnya Islam sebaliknya sangat dibutuhkan. Oleh sebab, persoalan pengungsi merupakan persoalan yang terkait erat dengan agama dikarenakan terjadi sebagai akibat dari konflik agama dan dampaknya tidak dapat dipisahkan dari konteks sosial budaya yang melingkupi negara asal dan negara penerima pengungsi.

Salah satu artikel mengenai pegungsi dari kacamata Islam ditulis oleh Hayatli (2012). Namun artikel tersebut berargumen bahwa Islam dan kebijakan pengungsi tidak kompatibel atau sejalan. Berbeda halnya dengan Hayatli, Shoukri (2010) memandang pengungsi sebagai konsep yang sudah ada sejak sejarah awal peradaban Islam. Sehingga, konsep jiwar (perlindungan) dan aman (keamanan) sudah diterapkan sejak lama.

Selain kajian terkait isu pengungsi, dibutuhkan alat analisis dalam meneliti kebijakan pengungsi berdasarkan perspektif Islam. Atas dasar itu, penelitian ini menggunakan pertama, international refugee protection rezime atau rezim perlindungan terhadap pengungsi internasional. Kedua, konsep Jiwar dan Aman yang menjadi basis dalam bagaimana Islam melihat pengungsi. Dalam pandangan Islam, pengungsi dianggap sebagai pihak yang harus dilindungi hal ini pada dasarnya sama dengan pandangan hukum internasional yang mengenai pengungsi.

Lebih lanjut, teori rezim perlindungan pengungsi pertama hadir ketika definisi pengungsi untuk pertama kalinya dimaknai secara internasional dalam Konvensi 1951 (Feller, 2001). Dalam teori ini rezim dimaknai sebagai alat hukum, termasuk perjanjian dan hukum nasional, yang menentukan atau melaksanakan kewajiban negara dan yang dimaksudkan untuk memastikan 
bahwa tidak ada pengungsi yang mencari suaka dihukum, diusir, atau diberhentikan, bahwa setiap pengungsi menikmati hak dan manfaat yang lengkap dia berhak sebagai pengungsi; dan bahwa hak asasi manusia dari setiap pengungsi adalah terjamin (Goodwin-Gill, 2014). Sehingga rezim perlindungan menjadi luas maknanya mencakup kerja sama dalam semangat solidaritas dan tanggung jawab dan pembagian beban di antara semua negara (Nicholson \& Kumin, 2017). Konsepsi rezim perlindungan pengungsi lahir dari pemahaman mengenai konsepsi negara bangsa yang berasal dari paradigma hukum internasional mengenai kedaulatan (Goodwin-Gill, 2014). Dalam pendekatan realism, negara - negara cenderung bertindak berdasarkan kepentingan nasional yang didasarkan pada rasionalitas. Hal ini termasuk dalam pembuatan kebijakan terkait pengungsi. Arus pengungsi yang masif dipandang sebagai ancaman keamanan (Nadig, 2002).

Feller (2001) mengungkapkan bahwa negara bangsa yang berada di bawah keanggotaan Perserikatan Bangsa-bangsa (PBB) baru melegalisasi konsep mengenai perlindungan dalam Konvensi 1951 terkait pengungsi namun, ketika itu konsep mengenai pengungsi masih terbatas semisal bagaimana mereka dianggap bukan sebagai warga negara. Sehingga tidak memiliki hak kewarganegaraan. Hingga kini pun, konsepsi mengenai perlindungan pengungsi masih terkendala perdebatan mengenai apakah perlindungan pengungsi penting karena melindungi hak individu atau karena perlindungan terhadap pengungsi merupakan kewajiban negara (Feller, 2001). Tarik menarik argumentasi inilah yang kemudian menjadikan lemahnya konsep mengenai rezim perlindungan pengungsi dalam memecahkan masalah riil di lapangan.

Tradisi panjang pemberian perlindungan dalam sejarah kemanusiaan menuntut adanya pemberian perlindungan bagi pencari suaka, baik yang Muslim maupun non-Muslim. Hal ini ditegaskan oleh Q.S. al-Taubah:6, yakni: "dan jika seorang diantara orang-orang musyrikin itu meminta perlindungan kepadamu, maka lindungilah ia supaya sempat mendengar firman Allah, kemudian antarkanlah ia ke tempat yang aman baginya; yang demikian itu disebabkan mereka kaum yang tidak mengetahui." Makna terdalam "permintaan perlindungan" (istijârah) tersebut ialah kebutuhan akan adanya payung perlindungan komprehensif bagi pencari suaka, keluarganya dan harta kekayaannya, terutama yang terkait dengan tempat-tempat suci.

\section{METODE PENELITIAN}

Persoalan mengenai pengungsi dan kebijakan merupakan permasalahan yang bersifat spesifik dan kontekstual. Untuk itu dibutuhkan langkah dan prosedur yang ilmiah dalam melakukan penelitian mengenai isu pengungsi yang kompleks. Untuk itu penelitian ini mengambil pendekatan penelitian kualitatif baik berdasarkan jenis data, teknik pengumpulan data maupun teknik analisis.

Jenis penelitian kualitatif yang digunakan adalah metode studi kasus dengan spesifik mengambil fokus kepada negara-negara mayoritas muslim. Hal ini bertujuan agar analisis dapat dilakukan dengan mendalam dan hasil yang diperoleh menjadi lebih holistik (Creswell \& Creswell, 2017). Adapun jenis data yang digunakan dalam penelitian ini adalah data melalui library research/kajian pustaka yakni laporan lembaga terkait, jurnal, buku, website, data UNHCR, maupun hasil penelitian sebelumnya terkait isu pengungsi. 


\section{PEMBAHASAN}

\section{A. Sikap dan Kebijakan yang Ditempuh oleh Negara-Negara Mayoritas Muslim Terkait dengan Isu Pengungsi yang Berasal dari Timur Tengah}

Persoalan pengungsi merupakan persoalan global. Dengan kata lain, masalah terkait pengungsi tidak semata persoalan nasional yang dihadapi oleh negara secara individu. Hal ini sebab meski persoalan pengungsi bukan hanya terjadi secara masif di satu dekade terakhir, namun situasi terutama di Timur Tengah pasca 11 September (Human Rights Watch, 2001) dan kemudian Arab Spring pada 2011 lalu (Republika, 2015) menjadikan situasi global sangat tidak kondusif. Timur Tengah bergejolak dan konflik berkepanjangan menyebabkan terjadinya arus pengungsi besar-besaran. UNHCR sebagaimana dikutip oleh Republika mencatat bahwa terdapat 219 ribu orang mengungsi menuju Eropa (Republika, 2015).

Seperti yang dikemukakan sebelumnya, kasus pengungsi tidak hanya bisa dilihat sebagai persoalan nasional yang merugikan negara namun pada dasarnya dampaknya bisa dirasakan secara internasional. Hal ini terutama dikarenakan karena konflik Timur Tengah telah terjadi bahkan jauh sebelum kasus 11 September. Hal tersebut dapat dilihat dari besarnya jumlah pencari suaka dari Timur Tengah ke berbagai negara di dunia. Salah satunya terdapat 27 juta orang Afganistan yang mengungsi ke luar negaranya (Human Right Watch, 2001). Kedua, terlalu banyaknya negara terutama di kawasan Timur Tengah yang tengah menghadapi ketidakstabilan politik dalam satu dekade terakhir. Bertitik tolak dari hal tersebut, penting untuk mengetahui dan memahami bagaimana sikap dan kebijakan negara-negara berpenduduk muslim terkait pengungsi Timur Tengah terutama oleh negara tujuan (host countries).

Sikap dan kebijakan negara-negara berpenduduk muslim sangat krusial untuk dikaji karena posisi dan peran mereka menjadi kunci dari keberhasilan dunia baik pemerintah maupun lembaga dan individu dalam menyelesaikan persoalan pengungsi. Mayoritas negara asal pengungsi adalah negara mayoritas muslim. Sayangnya, dari 57 negara Organisasi Kerjasama Islam (OKI), tidak semua negara memiliki sikap dan kebijakan yang jelas dalam menyelesaikan persoalan tersebut. Banyak dari negara tujuan dan negara yang fokus kepada isu pengungsi malah merupakan negara Barat. Hal ini tentu bukan tanpa alasan. Pertama, negara-negara tersebut memang merupakan tujuan utama dari pengungsi dan pencari suaka (dua istilah ini merujuk kepada dua hal yang berbeda). Kedua, negara-negara Barat memang memiliki sistem kebijakan publik yang mumpuni sehingga persoalan terkait dengan keamanan dan sosial budaya sangat diperhatikan. Meski demikian, hal tersebut tidak menjadikan tanggung jawab kemanusiaan sebagai sesama negara muslim lepas begitu saja. Negaranegara muslim terutama mereka yang tidak mengalami konflik dan dalam kondisi stabil sudah selayaknya menjadikan isu pengungsi sebagai agenda prioritas dalam kebijakan politik luar negerinya.

Untuk mengetahui sejauh mana isu pengungsi dapat menjadi isu bersama yang bisa menjadi fokus kerjasama internasional di antara sesama negara muslim terkhusus OKI, maka harus ada evaluasi terhadap kebijakan negaranegara tersebut dalam menyikapi isu pengungsi. Namun, dalam penelitian ini, kami berfokus kepada beberapa negara saja secara spesifik, kami menyajikan secara umum kebijakan yang dilakukan oleh sepuluh negara dengan jumlah pengungsi terbanyak yakni: Turki, Pakistan, Jerman, Iran, Lebanon, Amerika 
Serikat, Inggris (United Kingdom), Perancis, dan Kanada. Hal ini untuk melihat gambaran sikap dan kebijakan negara-negara tersebut dalam menghadapi isu pengungsi.

\section{a. Turki}

Turki berada pada wilayah yang strategis, menjadi batas antara benua Asia dan Eropa, negara ini termasuk dalam daerah yang menjadi tujuan pengungsi. Menurut data dari UNHCR, per Oktober 2017 ada sekitar 3,2 juta pengungsi Suriah di Turki. Kebanyakan dari mereka atau sekitar 44\% berasal dari Afghanistan, sedangkan $42 \%$ berasal dari Irak, dan 10\% dari Iran. Adapun sisanya berasal dari negara-negara lain di dunia.

Terkait pengungsi, Turki adalah salah satu penandatangan asli Konvensi Pengungsi 1951. Meski negara tersebut memberlakukan "batasan geografis". Batasan geografis ini terkait dengan mekanisme pengungsi. Pada bulan April 2013, Parlemen Turki mengeluarkan undang-undang penting terkait pengungsi yang baru dikenal sebagai Undang-Undang tentang Orang Asing dan Perlindungan Internasional (LRIP). Undang-undang ini mulai berlaku pada bulan April 2014. Dalam aturan tersebut ada beberapa perubahan aturan dalam sistem penerimaan pengungsi dan suaka namun mekanisme batasan geografis tetap berlaku. Hal ini membuat sebagian besar pengungsi tidak memiliki solusi jangka panjang untuk menetap di Turki (Refugee Solidatary Network, 2017).

Sebagai penandatangan Konvensi Pengungsi dan letaknya yang strategis, Turki menjadi mitra Uni Eropa (UE) dalam mengatasi isu tersebut. Pada 2016, keduanya membuat perjanjian tentang penanganan pengungsi. Kesepakatannya adalah Turki menghalau dan menampung pengungsi Suriah agar tak menyeberang ke kawasan Eropa. Dengan demikian, Eropa sebagai timbal baliknya memberikan bantuan dana sebesar enam miliar euro dan perjalanan bebas visa bagi warga Turki ke kawasan tersebut. Dana tersebut pada akhirnya digunakan untuk membiayai pembangunan sekolah, layanan kesehatan, dan tempat tinggal bagi pengungsi. Meski demikian, UE belum memenuhi janjinya dan Turki memutuskan untuk membiarkan pengungsi masuk ke wilayah Yunani (Republika, 2020).

Di luar tarik menarik politik antara UE dan Turki, dalam internal Turki sendiri ada berbagai upaya advokasi terkait pengungsi yang telah dilakukan di Turki semisal program pro bono for refugee protection yang dilakukan oleh berbagai NGO baik yang berasal dari luar dan dalam Turki (Refugee solidarity network, 2020).

\section{b. Pakistan}

Pakistan menjadi salah satu penerima pengungsi terbesar dikarenakan jumlah pengungsi dari Afganistan yang cukup besar sebagai akibat dari kedekatan geografis keduanya. Perbatasan kedua negara mencapai 1.560 mil sehingga arus pengungsi sulit untuk dikendalikan (Human Rights Watch, 2017: 6-7). Namun Pakistan bukanlah negara penandatangan Konvensi Pengungsi dan tidak memiliki aturan atau UU yang jelas terkait pengungsi. Landasan hukum yang digunakan hanyalah UU Orang Asing 1946 (UNHCRPK, 2020). Namun, rentannya wilayah perbatasan dengan Afganistan menyebabkan tidak adanya pilihan bagi Pakistan selain berdamai dengan kondisi pengungsi yang banyak datang dari negara tetangganya. 
Selain itu, UNHCR berperan besar dalam melobi negara tersebut untuk membiarkan pengungsi dari Afganistan untuk masuk ke sana. Penyerangan Afganistan oleh tentara Amerika Serikat menjadikan arus pengungsi ke Pakistan menjadi sangat besar. Pengungsi bahkan berjalan jauh dengan mencari rute alternatif demi masuk ke wilayah negara tetangganya tersebut. Pakistan dan UNHCR serta Lembaga Non Profit (NGO) kemudian bersepakat untuk mengakomodir satu juta pengungsi di wilayah perbatasan. Namun wilayah ini pada dasarnya tidak kondusif dikarenakan tidak sesuai dengan standar yang digunakan UNHCR. Meski demikian, otoritas Pakistan berdalih bahwa daerah ini akan dijaga secara ketat oleh militer Pakistan (Human Rights Watch, 2017: 7).

Kebijakan Pakistan memang cenderung menerima pengungsi, Perdana Menteri Pakistan Imran Khan bahkan pada 2018 berjanji memberikan kewarganegaraan bagi pengungsi dari negara tetangganya Afganistan (Tempo, 2018). Sikap dan kebijakan pemerintah Pakistan yang sepakat dengan UNHCR dan lembaga donor lainnya sayangnya berbeda dengan sikap dalam masyarakatnya. Berbagai penyerangan terhadap kantor lembaga asing di negara tersebut terjadi. Hal ini sebagai protes terkait dengan serangan militer Amerika Serikat dan Inggris yang dianggap mengacaukan wilayah kedua negara (Human Rights Watch, 2017).

\section{d. Jerman}

Di antara negara-negara Eropa, Jerman termasuk yang memiliki sikap positif terkait dengan penerimaan pengungsi (Kompas, 2018). Hal ini tidak lepas dari kepemimpinan Angela Merkel yang menerapkan kebijakan terbuka. Sikap Merkel ini tentu menuai pro dan kontra di dalam Jerman sendiri. Namun Merkel beralasan bahwa kebijakan tersebut merupakan keharusan bagi Jerman sebagai akibat dari tidak terbendungnya perpindahan manusia ke wilayah Eropa dan sikap anti pengungsi hanya akan menyebabkan dampak buruk yang lebih besar. Penolakan terhadap pengungsi akan menyebabkan tidak terkelolanya dengan baik mereka dan menyebabkan kondisi chaos sehingga meluas ke isu keamanan (Kompas, 2018).

Adapun pada dasarnya sikap dan kebijakan Jerman terhadap pengungsi dipengaruhi oleh sejarah masa lalu negara tersebut. Saat ini masyarakat Jerman jauh lebih dewasa dalam menerima perbedaan. Jerman lebih multikultural dan terbuka, hal ini tidak lepas dari sejarah buruk yang dimiliki negara tersebut. Pendudukan Nazi dan tindakan semena-mena mereka menyebabkan Jerman memiliki hutang kemanusiaan yang menjadikan negara tersebut lebih ramah terhadap pengungsi (CNN, 2015).

Namun banyak yang menilai bahwa sikap dan kebijakan Jerman yang pro pengungsi disebabkan oleh alasan mendasar lain yang lebih merupakan hitunghitungan politik dan tidak sekedar dilandasi oleh alasan kemanusiaan. Pertama, alasan bahwa kehadiran pengungsi menjadi jawaban atas kebutuhan Jerman terkait buruh murah. Kurangnya tenaga kerja yang tidak terampil membuat kedatangan pengungsi sebagai solusi terutama dalam ranah domestik. Kedua, secara ekonomi produktivitas Jerman mulai berkurang sebagai akibat dari kurangnya penduduk usia produktif. Dengan kedatangan pengungsi, secara umum industri Jerman yang membutuhkan tenaga kerja akan sangat terbantu. 


\section{e. Iran}

Iran diklaim oleh UNHCR pada 2017 sebagai negara yang ramah terhadap pengungsi. Bahkan Iran mendapat pujian atas sikapnya yang dianggap telah terbuka dalam menerima pengungsi. Iran sendiri telah menjadi tujuan pengungsi dari Afganistan selama empat dekade, dimana jumlahnya telah mencapai dua juta orang (Tempo, 2017). Iran sendiri merupakan negara yang tunduk terhadap Konvensi Pengungsi 1951 yang mewajibkan negara tersebut untuk membuka wilayahnya bagi pengungsi atau paling tidak memberi perlindungan sementara bagi pengungsi yang masuk ke negaranya (Human Rights Watch, 2017: 3).

Pada 2019, Iran menjadi negara penerima pengungsi terbesar kedua di Asia dan keenam di dunia. Pengungsi terbesar yang masuk ke Iran adalah pengungsi dari Afganistan dan Irak. Jumlah Pemerintah Iran bersama UNHCR dan pemerintah Afganistan dan Pakistan membentuk Support Platform for the Solution Strategy for Afghan Refugee. Data menunjukkan bahwa lebih dari 950 ribu pengungsi Afganistan bermukim di Iran. Belum termasuk pengungsi ilegal yang jumlahnya mencapai 2 juta orang. Selain itu UNHCR telah membangun sejumlah sekolah untuk anak-anak pengungsi dan memberikan layanan kesehatan gratis bekerjasama dengan kementerian Pendidikan dan juga Kementerian Kesehatan Iran (UNHCR, 2020).

Iran memang memiliki kebijakan progresif terkait pengungsi dengan dukungan penuh dari UNHCR terutama dalam hal pendanaan. Namun sikap dan kebijakan Iran ini berbeda dengan sikap dan kebijakannya di awal-awal masifnya arus pengungsi setelah 11 September. Ketika itu pemerintah Iran melakukan upaya sendiri dengan memberikan membangun tenda pengungsian dengan persetujuan Taliban dan tidak melibatkan UNHCR ataupun lembaga kemanusiaan lainnya (Human Rights Watch, 2017).

\section{f. Lebanon}

Lebanon bukanlah negara penandatangan Konvensi Pengungsi 1951, sehingga tidak mengherankan negara tersebut (Library of Congress, 2016), sebagaimana kebanyakan negara lainnya memiliki kebijakan yang naik turun terhadap pengungsi. Lebanon hanya menandatangani Mutual of Understanding (MoU) dengan UNHCR terkait dengan penanganan pengungsi sejak 2003. Salah satu yang terpenting dari kesepakatan tersebut adalah adanya izin tinggal atau residence permit yang dikeluarkan pemerintah Lebanon selama kurun waktu sekitar tiga hingga enam bulan. Namun setahun terakhir yakni sejak 2019 negara ini mengeluarkan kebijakan terbaru yang lebih jelas dan ketat terkait dengan pengungsi Suriah seperti pemberlakuan jam malam dan repatriasi (Migration Policy Institute, 2019). Meski UNHCR melakukan upaya pendekatan untuk melobi Lebanon agar tetap memperhatikan hak-hak pengungsi. Pengungsi dari Suriah memang merupakan pengungsi terbanyak yang masuk ke Lebanon sebagai dampak dari Arab Spring yang berkecamuk. Ada sekitar 1,5 juta pengungsi Suriah yang menetap di Lebanon (UNHCR, 2020). Lebanon juga merupakan negara dengan jumlah pengungsi perkapita terbesar di dunia (Migration Policy Institute, 2019).

Sikap Lebanon yang tidak terlalu ramah terhadap pengungsi dalam beberapa tahun terakhir merupakan akibat dari krisis ekonomi yang terjadi di negara tersebut. Ada sekitar 28 persen masyarakat Lebanon yang hidup di 
bawah garis kemiskinan (Migration Policy Institute, 2019). Kondisi sosial ekonomi yang tidak kondusif menyebabkan kehadiran pengungsi sebagai ancaman dan beban. Selain itu faktor kekhawatiran adanya sektarian muslim juga turut andil dalam persoalan pengungsi versus masyarakat lokal. Lebanon memiliki penduduk Kristiani yang cukup besar dan persentasi Sunni dan Shiah cukup berimbang. Sedangkan pengungsi yang datang kebanyakan adalah muslim Sunni. Sejarah masa lalu Lebanon dan Suriah juga tidak terlalu baik (Migration Policy Institute, 2019).

\section{g. Amerika Serikat}

Amerika Serikat memiliki kebijakan yang sangat dipengaruhi oleh partai apa yang tengah berkuasa. Namun sejak awal negara tersebut telah dikenal sebagai aktor penting dalam isu pengungsi. AS memiliki sejarah panjang terkait pencari suaka dan karena itu memiliki nilai-nilai dasar yang kental terhadap multikulturalisme. AS bahkan hingga kini masih menjadi negara tujuan pengungsi terbesar di dunia. Pengungsi terbanyak berasal dari kawasan Afrika kemudian Asia. AS juga memiliki berbagai NGO yang bergerak dalam bidang pengungsian (UNHCR, 2020).

Terkait dengan sikap dan kebijakan AS, terjadi perbedaan mencolok jika berkaca kepada kepemimpinan Trump versus Obama. Di bawah kendali Trump, AS menurunkan jumlah pengungsi jauh di bawah angka di masa pemerintahan Obama. AS sangat ketat dalam memberlakukan aturan kedatangan dan izin tinggal serta memberlakukan aturan keamanan yang tidak ramah terhadap pengungsi. Masuknya penduduk dari beberapa negara dilarang seperti Sudan, Suriah, Iran Libya, Somalia dan Yemen (World Relief, 2020). Bahkan pada 2017 untuk pertama kalinya dalam sejarah AS, angka pengungsinya jauh lebih rendah dari rata-rata pengungsi di dunia (UNHCR, 2020).

Sedangkan di masa Obama, pada 2016 lalu, terdapat 90 ribu pengungsi yang diterima dan pada 2017 di awal tahun ada 24 ribu pengungsi yang masuk ke AS. Bahkan menyetujui tambahan pengungsi pada akhir 2017 dan mayoritas pengungsi tersebut merupakan keturunan muslim (World Relief, 2020). Meski kebijakan Trump dan Obama berbeda, AS memang telah memiliki sistem yang canggih dalam menangani pengungsi. AS memiliki program terkait dengan pengungsi yang sudah dikelola dengan baik setara dengan yang telah dilakukan UNHCR. Hal ini tidak mengherankan terutama karena AS memiliki pendanaan dan fasilitas yang memadai. Sistem yang canggih terkait dengan pengungsi ini juga menyebabkan proses untuk mendapatkan persetujuan masuk ke AS tidak mudah meskipun ada perlindungan yang baik yang disediakan pemerintah AS kepada pengungsi.

\section{h. Inggris}

Inggris memiliki program yang jelas terkait dengan pengungsi dan sesuai dengan standar internasional yang melindungi hak-hak asasi pengungsi. Inggris memang memiliki sistem yang sudah mapan seperti halnya AS dalam soal penanganan pengungsi. Hal ini karena isu pengungsi juga telah lama dihadapi oleh Inggris. Lembaga advokasi yang bergerak dalam isu ini juga termasuk banyak termasuk di dalamnya Refugee Council (Refugee Council, 2020). Namun negara tersebut bukan hanya negara penerima pengungsi terbesar. Pada akhir 2018, data UNHCR menyebutkan bahwa ada sekitar 126,720 pengungsi di negara tersebut. Jumlah yang masih lebih kecil dibandingkan AS. Adapun 
pengungsi dikelola dalam beberap program seperti Gateway Protection Programme, the Mandate Scheme, the Vulnerable Children Resettlement Scheme (VCRS), or the Syrian Vulnerable Person's Resettlement Scheme (VPRS) (UNHCR, 2020).

Dalam internal Inggris sendiri, dorongan untuk menerapkan sikap dan kebijakan pro pengungsi telah gencar terutama sejak 2015 saat pengungsi besar-besaran Suriah tiba di negara tersebut. Ada sekitar 5000 pengungsi Suriah yang masuk ke Inggris hingga kini. Meski pihak pemerintah Inggris tidak serta merta membuka negaranya (BBC, 2015). Gencarnya dorongan untuk menerima pengungsi memang sangat besar karena Inggris diharapkan bisa membawa pesan-pesan kemanusiaan dan berbuat lebih banyak di tengah krisis pengungsi yang terjadi dalam satu dekade terakhir.

\section{i. Perancis}

Sikap dan kebijakan Perancis terkait pengungsi memang sejak lama tidak terlalu ramah. Pada 2018 bahkan pemerintah Perancis mengeluarkan RUU terkait kebijakan suaka yang lebih ketat. Hal ini menurut pemerintah Perancis dikarenakan kebijakan sebelumnya yang terlalu longgar menyebabkan masifnya jumlah pengungsi. Hal ini dianggap oleh banyak pihak sebagai sikap sentiment anti pengungsi kepada presiden Emanuel Macron (NY Times, 2019). Beberapa aturan tersebut semisal aplikasi suaka yang diajukan bisa ditolak dan tidak dapat lagi mengajukan kembali. Di sisi lain mereka akan diberikan dana untuk kembali ke negara asalnya (Tempo, 2020). Pemerintah Perancis beranggapan bahwa selama ini Perancis terlalu atraktif sebagai negara tujuan pengungsi dan kebijakan mereka digunakan oleh imigran atau pengungsi untuk seenaknya (NY Times, 2019). Padahal pengungsi secara hakikatnya melakukan migrasi dengan alasan ketidakamanan atau keterpaksaan. Sehingga opsi untuk pulang kembali ke negara mereka menjadi terkesan tidak ramah terhadap mereka.

\section{j. Kanada}

Kanada seperti halnya AS dan Inggris merupakan aktor terdepan dalam penanganan pengungsi global. Bahkan Kanada dalam beberapa tahun terakhir dianggap sebagai negara dengan perlindungan terbaik dalam hal pengungsi dan pencari suaka. Negara ini telah menandatangani Konvensi Pengungsi 1951 dan memiliki panduan yang jelas terkait dengan pengungsi perempuan (Amnesty, 2020). Di tahun 2018, Kanada tercatat sebagai negara kedua dengan jumlah pengungsi yang mendapatkan kewarganegaraan baru (Global News, 2019).

Selain itu, Perdana Menteri Kanada mengambil jalan berbeda dengan yang dilakukan oleh Donald Trump dengan membuka Kanada terhadap pengungsi dan pencari suaka muslim (Tempo, 2017). Justin Trudeau mengatakan bahwa Kanada terbuka terhadap siapa saja karena keberagaman adalah kekuatan negara tersebut (Tempo, 2017). Kanada sendiri memiliki Canadian Refugee Protection Program yang berfokus kepada penanganan pengungsi dan pencari suaka. Bekerja sama dengan UNHCR, pemerintah Kanada memastikan bahwa pengungsi dilindungi hak-haknya. Keterlibatan lembaga swasta dan NGO juga sangat krusial di Kanada. Ada berbagai fasilitas dan subprogram yang ditawarkan oleh Pemerintah Kanada mulai dari childcare, akses tempat tinggal dan berbagai hal lainnya. 


\section{B. Strategi Kebijakan yang Bisa Dilakukan oleh Negara-Negara Mayoritas Muslim Secara Bersama untuk Mengatasi Isu Pengungsi.}

Negara-negara mayoritas yang dimaksud di sini ialah negara-negara anggota OKI, dimana negara-negara yang berpenduduk mayoritas Muslim berkumpul. Tujuan dari OKI yaitu untuk meningkatkan solidaritas Islam di antara negara-negara anggota, mengkoordinasikan kerja sama antar negara anggota, mendukung perdamaian dan keamanan internasional di bidang sosial, ekonomi, budaya, ilmiah, dan politik; menjunjung tinggi perdamaian dan keamanan internasional; dan memajukan pendidikan, khususnya di bidang iptek serta melindungi tempat-tempat suci Islam (History of The Organisation of Islamic Cooperation (OIC), 2020). Akan tetapi, OKI telah dikritik oleh banyak Muslim karena kurangnya keterlibatan dan solusi nyata bagi negara-negara Muslim yang dilanda krisis, walaupun membuat kemajuan dalam hal sosial dan akademis tetapi tidak secara politik (OIC: 40 Years of Frustrations Al Jazeera, 2009). Olehnya itu penting untuk bisa mengetahui dan memahami seperti apa sebaiknya strategi kebijakan jangka pendek dan jangka panjang yang bisa dilakukan oleh negara-negara mayoritas muslim (OKI) secara bersama, untuk mengatasi isu pengungsi terutama yang berasal dari timur tengah.

Sebagai program jangka pendek (kurang dari 1 tahun) telah dilakukan pembentukan tim penyelamatan darurat pengungsi. Pemimpin negara-negara OKI, dapat memprioritaskan untuk mengutamakan menyelamatkan nyawa pengungsi terlebih dahulu, disebabkan karena hampir 7.000 orang dalam perjalanan laut pengungsian telah tenggelam di Mediterania dalam dua tahun belakangan, sejak kapal karam besar pertama pada Oktober 2013. Pemberian izin bebas tinggal atau melintasi negara juga diberikan bagi pengungsi darurat. Bagi pengungsi, apakah mereka melakukan perjalanan melalui darat atau laut, orang-orang yang melarikan diri dari penganiayaan atau perang, agar bisa diberikan kebijakan agar dilonggarkan dan diizinkan untuk melintasi perbatasan negara, baik dengan atau tanpa dokumen perjalanan. Apabila ada negara yang mendorong pengungsi mundur dan atau memasang pagar besar pembatas (agar tidak bisa lewat) hanya akan memaksa mereka untuk mengambil rute yang lebih berbahaya.

Pemberian jaminan kesehatan yang memadai. Kesehatan yang buruk memengaruhi kemampuan pengungsi untuk beraktivitas dan berinteraksi dengan banyak hal, dengan pengungsi yang rentan terhadap masalah kesehatan, khususnya masalah mental seperti kecemasan dan depresi. Negara OKI sebaiknya memberikan bantuan jaminan kesehatan yang memadai, khususnya dalam kesehatan mental pengungsi, bersamaan juga dengan pemeriksaan fisik mereka. Selanjutnya penggalangan dana internasional juga dilakukan. Negara OKI bisa menjadi pioner dalam melakukan penggalangan bantuan seperti crowdfunding, untuk memberikan dana bantuan jangka pendek (ataupun panjang) dalam memenuhi kebutuhan ekonomi jangka pendekmenengah terutama di bidang kesehatan, sambil menunggu keputusan hal lainnya terkait status pengungsinya ke depan.

Peningkatan edukasi dan kemandirian pengungsi diharapkan pemerintah Negara OKI bekerja sama dalam menerima pengungsi ke beberapa daerah di negaranya, agar mempertimbangkan di mana pekerjaan yang sesuai dan cocok dengan keterampilan masing-masing pengungsi. Misalnya, di Swedia para migran dicocokkan dengan lokalitas (daerah) berdasarkan profil mereka secara 
keseluruhan, termasuk tingkat pendidikan dan pengalaman kerja mereka (World Economic Forum, 2016), hal ini agar pengungsi dapat sedikit terbantu dalam menopang kehidupan selama di pengungsian sambil menunggu kelanjutan status pengungsinya. Peningkatan kerja sama Negara OKI dengan berbagai Lembaga tidak hanya pemerintah (penampung pengungsi) yang ingin mendukung pengungsi untuk berintegrasi, pengusaha, badan amal, asosiasi imigran, organisasi berbasis komunitas dan semua lembaga terkait memiliki peran untuk dimainkan. Misalnya dengan bekerja sama (pemerintah dan swasta), mengembangkan program mentorship, meningkatkan keterampilan pengungsi dalam pembauran sebagai pendatang baru di suatu masyarakat.

Negara OKI juga memberntuk tim keamanan pengungsi muslim. Negara OKI harus senantiasa waspada serta menyelidiki kelompok-kelompok perdagangan manusia, yang mengeksploitasi pengungsi dan migran. Tidak sedikit para pengungsi mengatakan bahwa para penyelundup tidak segan untuk membunuh orang di atas kapal ketika keluarga mereka tidak bisa membayar uang tebusan, sedangkan lainnya terlempar ke laut dan dibiarkan tenggelam, atau mati karena tidak ada makanan dan air (Amnesty International, 2015). Negara-negara OKI khususnya yang mempunyai GDP besar seperti Indonesia, Arab Saudi, UEA dan lainnya, dapat membantu semaksimal mungkin, baik barang maupun jasa dalam membantu pengungsi yang berada di berbagai negara, khususnya di negara yang ditempati belum cukup memadai pelayanannya.

Sebagai program jangka panjang dilakuka penguatan kerja sama keamanan internasional secara masif dan terukur. Negara-negara OKI khususnya yang mempunyai GDP besar, seperti Arab Saudi, UEA, Indonesia dan lainnya, sedapat mungkin menjalin kerja sama dengan berbagai pihak, termasuk PBB dalam menyelesaikan konflik yang terjadi, karena umumnya pengungsi, berasal dari negara yang dilanda konflik. Pembukaan jalur khusus suaka dilakukan oleh negara-negara OKI agar dapat bekerja sama dalam membuatkan jalur khusus, yaitu 'jalur aman menuju suaka' dan dilengkapi fasilitas keselamatan yang cukup, hal ini merupakan salah satu hal penting, khususnya dalam menjaga keselamatan dan keamanan mereka selama perjalanan.

Pemberian kelonggaran pengungsi mencari nafkah. Negara-negara OKI yang menerima pengungsi, selain memberikan bantuan tunai jangka pendekmenegah, sebaiknya para pengungsi diberikan hak untuk memenuhi kebutuhannya dengan memperbolehkan mencari nafkah (bekerja) secara legal dan berkelanjutan, hal ini agar pengungsi lebih mandiri daripada hanya bergantung dari bantuan yang mungkin belum tentu selalu diterima. Sebagai contoh, Uganda, yang memiliki jumlah pengungsi terbesar kedelapan di dunia, memperlakukan pengungsi sebagai pengungsi yang produktif. Lebih dari setengah juta (pengungsi) yang berasal dari Kongo, Sudan Selatan, Burundi, dan Somalia tinggal di sana. Seperti yang didokumentasikan oleh Pusat Studi Pengungsi di Oxford dan sumber-sumber lain, mereka diberikan sebidang tanah untuk bertani dan dapat bekerja secara legal, pindah ke tempat yang mereka inginkan, dan memilih tempat tinggal. Mereka dapat menggunakan layanan publik, menyekolahkan anak-anak mereka ke sekolah umum, meningkatkan keterampilan mereka, dan berkontribusi pada perekonomian Uganda. Di Kampala, 78 persen pengungsi tidak membutuhkan bantuan, dan secara 
nasional hanya 1 persen yang sepenuhnya bergantung pada bantuan (International Rescue Committee (IRC), 2016).

Sebagai bentuk tindak lanjut deberikan beasiswa bagi pengungsi. Negaranegara OKI dapat memberikan beasiswa khusus bagi pengungsi, karena selain bantuan kebijakan kelonggaran kebolehan bekerja bagi pengungsi, sebagian besar anak pengungsi berada dalam masa sekolah, akan tetapi bisa jadi sedikit atau tidak sama sekali mengecap pendidikan formal yang disediakan, dan membutuhkan dukungan yang spesifik dan tepat untuk mengejar ketinggalan mereka, sehingga diharapkan menjadi 'penggerak' di kemudian hari.

Dalam memeperoleh dukungan lembaga keuangan internasional negaranegara OKI dapat secara khusus bekerjasama dengan Lembaga keuangan internasional seperti Bank Dunia, dalam memberikan dukungan ekonomi yang memadai kepada negara-negara yang menampung pengungsi, karena sangat penting untuk menyelaraskan kepentingan pengungsi dan negara tuan rumah, seperti adanya kebijakan pembiayaan khusus dengan harga (atau bunga) lebih rendah dari harga pasar, dan produk asuransi khusus untuk negara-negara penampung yang berpenghasilan rendah. Dengan adanya bantuan kebijakan keuangan tersebut, secara tidak langsung membantu pemerintah penampung pengungsi dapat lebih longgar bergerak membantu para pengungsi.

Bantuan penempatan ke negara suaka (resettlement/ pemukiman kembali). Negara-negara OKI dapat bekerja sama dengan berbagai negara khususnya yang telah tergabung dalam OKI agar dapat secara resmi menempati negara suaka dan menjadi penduduk legal. Adanya pemukiman kembali adalah solusi penting bagi pengungsi karena mereka telah legal sebagai warga di suatu negara, khususnya bagi pengungsi berumur tua dan atau korban penyiksaan dan orang-orang dengan masalah kesehatan medis serius, karena jika status mereka masih belum jelas atau pengungsi, tidak menutup kemungkinan mereka dapat dipindahkan ke negara dan atau di daerah lainnya.

Edukasi ke masyarakat terkait problem pengungsi dilakukan dengan membuat Tim atau Sosialisasi Khusus dalam mengedukasi masyarakat, khususnya di negara yang menerima pengungsi, agar tidak terjadi konflik antara pengungsi (pendatang) dan masyarakat sekitar. Termasuk dalam meluruskan kekeliruan, adanya anggapan bahwa pengungsi dan migran membawa masalah ekonomi dan sosial, dan sebaliknya memerangi semua jenis xenofobia, diskriminasi rasial dan lainnya. Jika tidak ditangani dengan baik, dapat menimbulkan konflik yang kadang berkepanjangan serta menimbulkan ketegangan dan ketakutan terhadap orang asing, dan terkadang mengarah pada kekerasan bahkan kematian. Seperti yang terjadi di Durban, Afrika Selatan, setidaknya empat orang tewas, banyak yang terluka parah, dan lebih dari 1.000 pengungsi Burundi dan Kongo terpaksa mengungsi setelah kekerasan dan penjarahan terjadi pada April dan Mei 2015 (Human Rights Watch, 2019).

\section{Ajaran Islam terkait Pengungsi dan Peran strategis Indonesia dalam membangun kebijakan strategis kolektif di antara negara mayoritas Muslim. \\ Kesejahteraan Sosial dalam Islam}

Dalam ajaran Islam, gagasan kesejahteraan sosial telah dihadirkan sebagai salah satu nilai pokoknya (Ahmad, 1997; Stefon, 2010; Palmer, 2012), kehidupan religius seorang Muslim tetap tidak lengkap jika tidak diikuti oleh 
pengabdian kepada kemanusiaan (Stefon, 2010). Ayat Al-Quran berikut ini sering dikutip untuk merangkum gagasan Islam tentang kesejahteraan sosial (Corrigan, 2016):

Bukanlah menghadapkan wajahmu ke arah timur dan barat itu suatu kebajikan, akan tetapi sesungguhnya kebajikan itu ialah beriman kepada Allah, hari kemudian, malaikat-malaikat, kitab-kitab, nabi-nabi dan memberikan harta yang dicintainya kepada kerabatnya, anak-anak yatim, orang-orang miskin, musafir (yang memerlukan pertolongan) dan orang-orang yang meminta-minta; dan (memerdekakan) hamba sahaya, mendirikan Shalat, dan menunaikan zakat; dan orang-orang yang menepati janjinya apabila ia berjanji, dan orang-orang yang sabar dalam kesempitan, penderitaan dan dalam peperangan. Mereka itulah orang-orang yang benar (imannya); dan mereka itulah orang-orang yang bertakwa. (QS. 2: 177).

Demikian pula kewajiban kepada orang tua, tetangga, kerabat, orang sakit, orang tua, kelompok minoritas dan termasuk pengungsi telah disinggung dalam Islam. Dalam sebuah hadis panjang yang tercatat dalam Hadits Qudsi, dikatakan bahwa Allah SWT. pada hari kiamat akan tidak senang dengan orangorang yang tidak peduli pada orang yang sakit, dan yang tidak memberikan makanan kepada mereka yang memintanya. Allah SWT. akan menginterogasi mereka dan menuntut penjelasan dari mereka. Hadits ini dipandang sebagai pengingat kewajiban manusia untuk memenuhi kebutuhan orang lain (Cornell, 2007). Individu, keluarga, negara dan organisasi non-pemerintah dan pemerintah - semua bertanggung jawab atas pelaksanaan tanggung jawab sosial, dan untuk meningkatkan kesejahteraan sosial. Al-Qur'an mengatakan bahwa orang-orang beriman telah diutus untuk kemajuan umat manusia, bahwa mereka akan melakukan apa yang baik, dan mencegah apa yang dilarang dalam Islam (QS. 3: 110 ). Namun, ini harus dilakukan dengan cara terbaik: tidak ada kehormatan individu yang boleh dirugikan, dan tidak ada kerugian yang harus ditimbulkan karenanya (Hashmi, 2009).

\section{Islam dan Penolakan Diskriminasi Rasial}

Dalam sejarah manusia, diskriminasi rasial telah lama menjadi penyebab ketidakadilan (Gillroy, 2002; Juan, 2004). Salah satu aspek penting dari ajaran Islam adalah bahwa Islam menganggap sesama manusia ialah 'setara', Islam tidak mengakui diskriminasi rasial antar manusia, bahkan di akhir hayat Nabi, menyangkal diskriminasi berdasarkan ras dan warna kulit, bahasa atau suku, semua dianggap setara dalam menerima hak asasi manusia dan dalam menjalankan tugas, serta tidak ada kelas yang diistimewakan kecuali mereka yang memiliki kesalehan atau keunggulan moral (Hashmi, 2009). Al-Qur'an juga melarang Muslim untuk meremehkan orang lain, dengan asumsi bahwa akan ada perbedaan alami dalam status sosial dan pendapatan di antara individu yang merupakan hasil alami, karena perbedaan bakat dan upaya pribadi, memunculkan rasa persaudaraan dengan sesama Muslim dan rasa kemanusiaan terhadap setiap manusia telah disarankan untuk dibudayakan, untuk lebih membangun kesetaraan dalam masyarakat (Hashmi, 2009).

\section{Islam dan Pengungsi}

Suaka merupakan hak siapa pun. Dalam Islam, suaka adalah hak siapa pun yang mencari perlindungan, dalam studinya tentang suaka dalam ajaran 
Islam, G.M. Arnaout berpendapat bahwa suaka 'merupakan bagian integral dari konsepsi Islam 'tentang hak asasi manusia'. Islam merangkul orang-orang dari berbagai ras, kebangsaan, dan etnis. Ide-ide Islam tentang suaka dan pengungsi mencerminkan inklusivitas agama ini. Al-Qur'an, berbicara secara eksplisit tentang masalah pencari suaka dan pengungsi: Dan jika ada orang kafir yang mencari perlindungan Anda, maka berikan dia perlindungan sehingga dia dapat mendengar firman Allah, dan kemudian mengantar dia ke tempat dia akan aman. (QS. 9: 6).

Konsep 'aman' (ma'manah) yang ada pada QS. 9: 6 di atas, mencakup hakhak pengungsi dan pencari suaka serta kewajiban yang menjadi tanggung jawab tuan rumah. Aman juga mengacu pada perlindungan dan perlindungan yang ditawarkan kepada non-Muslim, bahkan jika mereka berkonflik dengan Muslim, dan mengharuskan populasi tuan rumah memfasilitasi pemulangan pengungsi secara sukarela ke tempat asal mereka jika dianggap aman. Al-Qur'an juga menetapkan peraturan tertentu untuk memberikan dukungan tambahan kepada perempuan dan anak-anak, yang dianggap lebih rentan [QS. 4: 2, 9, 36, 75, 98, 127, QS. 17: 34]. Berdasarkan prinsip keadilan, yang menjadi dasar dari semua peraturan Islam [QS. 42: 15, QS. 16: 90], mereka yang lebih berisiko akibat migrasi dan suaka harus diberi dukungan ekstra. Ini juga berlaku untuk nonMuslim atau mereka yang menentang keyakinan Muslim [QS. 5: 8]. Beberapa hak pengungsi dan pencari suaka dalam Islam, terutama perempuan dan anakanak (Worldwide, 2012):

a. Semua orang yang melarikan diri dari penganiayaan berhak atas suaka dan hak-hak yang terkait dengan status tersebut.

b. Langkah-langkah untuk memenuhi kebutuhan individu-individu ini adalah tugas publik.

c. Pengungsi tidak boleh dibiarkan rentan terhadap penganiayaan dan ketidakadilan.

d. Hak perempuan dan anak di negara tuan rumah sama dengan hak perempuan dan anak yang mengungsi di sana [QS. 8: 75]. Itulah sebabnya Nabi menyatakan persaudaraan antara Muhajirin dan Anshar dan menyatakan bahwa "Hak para pendatang adalah sama dengan tuan rumah mereka". Dengan kata lain, perempuan dan anak-anak tersebut, baik didampingi oleh keluarga mereka atau tidak, harus diberi perlindungan yang sama dengan perempuan dan anak-anak dari negara tuan rumah.

e. Setiap keputusan yang berkaitan dengan pengungsi anak, harus mempertimbangkan kepentingan dasar mereka [QS. 2: 220]. Mereka berhak atas pendidikan dan pendidikan yang sehat. Dari perspektif Islam, anakanak tidak bersalah, bakat mereka harus dipupuk [QS. 4: 2-4] dan mereka tidak boleh didiskriminasi.

f. Anak-anak dan perempuan, lebih rentan, harus diperlakukan dengan tindakan afirmatif (diskriminasi positif). Nabi menegaskan hak-hak perempuan dan anak-anak lebih dari kelompok lainnya. Pengungsi anakanak dan wanita termasuk di antara orang-orang yang paling terpinggirkan di dunia dan Muslim harus mengalokasikan sebagian dari upaya untuk mendukung mereka. Dari perspektif agama, apa yang ditawarkan kepada individu-individu ini adalah hak mereka [QS. 70: 24, 25]. Jika wali anak diberikan suaka, maka anak tersebut harus diberi status yang sama, sehingga menjaga hak anak untuk tetap tinggal bersama keluarganya. 
g. Hak individu-individu ini untuk dipersatukan kembali dengan keluarga mereka harus dihormati. Jika orang tua dari anak-anak ini tidak ditemukan, kerabat anak-anak tersebut harus memberikan perlindungan. Mereka harus dibantu untuk kembali ke tempat asalnya jika negaranya tersebut dianggap aman [QS. 9: 6].

Penerapan Keadilan. Al-Qur'an memiliki banyak referensi tentang keadilan, terutama pentingnya menciptakan masyarakat yang adil, dan memberikan kerangka kerja keadilan dalam hubungan antar pribadi, terhadap yang miskin dan membutuhkan, dan hubungan antara komunitas dan negara. Konsepkonsep ini merupakan bagian integral dari Islam. Pada 662 M, Nabi Muhammad SAW. melarikan diri dari penganiayaan di Mekah dan mencari perlindungan di Madinah. Hijrah, atau migrasi, ini melambangkan perpindahan umat Islam dari tanah penindasan. Selain itu, perlakuan ramah terhadap Muhammad SAW. oleh orang-orang Madinah mewujudkan model perlindungan pengungsi Islam yang terkandung dalam Al-Qur'an.

Sikap Penerimaan Pengungsi. Islam mewajibkan masyarakat tuan rumah (daerah yang ditempati pengungsi) untuk memberikan sambutan yang murah hati kepada pencari suaka. Hukum Islam, atau Syariah, menegaskan praktik menyediakan perlindungan bagi orang-orang yang teraniaya dan kesucian tempat-tempat, seperti Ka'bah di Mekah. Siapa pun yang mengungsi di masjid atau di rumah sahabat Nabi Muhammad (SAW) aman dan terjamin. Al-Qur'an memberikan seperangkat instruksi dalam menangani pengungsi dan migran, memuji mereka yang pergi membantu orang-orang yang dalam kesusahan dan membutuhkan umat beriman untuk melindungi pengungsi [QS. 9: 100 dan 117]. Undang-undang ini memberikan hak kepada pengungsi dan pengungsi internal untuk mendapatkan hak-hak tertentu dan perlakuan yang manusiawi [QS. 8: 72-75, QS. 16: 41] dan mengutuk orang-orang yang tindakannya mendorong migrasi massal [QS. 2: 84-86] .

Migrasi dan Pengungsi adalah suatu Kewajaran. Banyak contoh migrasi oleh orang beriman dan nabi muncul di Al-Qur'an dan dalam sejarah Islam. Mereka tidak hanya mengacu pada migrasi umat Islam tetapi juga kisah-kisah dari Nabi seperti Ibrahim dan Musa. Ayat-ayat Al-Qur'an menunjukkan bahwa migrasi dapat menjadi kebutuhan bagi siapa pun di saat sulit atau saat kehidupan dan keyakinannya terancam. Beberapa ayat bahkan meminta umat untuk memilih migrasi dalam situasi seperti itu (jika mereka mampu melakukannya) [QS. 4: 97-99].

Keberpihakan Ajaran Islam. Konsep Islam tentang pengungsi dan suaka memiliki ciri khas utama. Dalam ajaran Islam, hijrah (suaka) memberikan definisi yang lebih luas daripada definisi pengungsi dalam Pasal 1 Konvensi 1951, yang Berkaitan dengan Status Pengungsi. Dalam Islam, semua pengungsi harus diperlakukan sama di bawah kedaulatan Tuhan (Allah SWT). Sebaliknya, hukum Barat, berdasarkan kedaulatan negara, membagi orang-orang terlantar menjadi: a) pengungsi, b) pencari suaka, c) orang-orang tanpa kewarganegaraan, d) pengungsi internal, e) pengungsi yang kembali, dan f) orang-orang yang berisiko dipindahkan, dan kelompok-kelompok ini berbeda hak dan kewajibannya. Ini mengabaikan fakta, bahwa tidak sedikit dari pengungsi tertentu, seperti perempuan dan anak-anak, lebih rentan daripada yang lain, sehingga adanya kategorisasi tersebut dapat memperburuk keadaan jika tidak diantisipasi. 
Kontras utama kedua antara hukum pengungsi modern dan hukum Islam adalah menunjukkan kekuasaan pemberi suaka. Hukum internasional modern tidak memiliki ketentuan yang memberikan hak penuh kepada pencari suaka atas suaka. Dalam hukum internasional, hanya negara yang memiliki kekuasaan untuk memberikan suaka.

\section{Indonesia, OKI dan Pengungsi}

Di seluruh dunia, saat ini terdapat lebih dari 1,3 miliar Muslim. Kebanyakan pengungsi Muslim melarikan diri dari konflik bersenjata yang kejam atau rezim otoriter di negara mereka. Namun, meskipun mereka menganut Islam atau hukum Syariah, negara-negara Muslim jarang menyebut dan mengartikulasikan 'hijrah' ketika berurusan dengan pengungsi. Konsep dasar ajaran Islam ini jarang diterapkan, hal ini dapat dilihat dimana yang selama ini, yang banyak menampung pengungsi dari sisi banyaknya negara OKI yang diterima sebagai pengungsi dan pemukiman kembali, mayoritas berasal dari negara Barat sebagaimana dikemukakan sebelumnya. Namun, terlepas dari kurangnya penerimaan suaka khususnya di Negara OKI, konsep hijrah dapat memberikan kerangka kerja yang penting untuk perlakuan terhadap pengungsi dan pencari suaka oleh negara mayoritas Muslim.

Ajaran dan peraturan Islam merupakan sumber yang berharga untuk perlindungan hak-hak pengungsi, migran dan pencari suaka. Selain tanggung jawab kontrak, mereka dapat berfungsi sebagai penjamin hak-hak pengungsi, terutama wanita dan anak-anak, berdasarkan agama. Jalinan kerja sama Indonesia dengan negara di Timur Tengah cukup terlibat, terutama ketika Kemerdekaan Indonesia 1945, negara yang mengakui Kemerdekaan Indonesia ialah negara-negara yang berasal dari Timur Tengah (Mesir, Siria, Irak, Saudi Arabia, Yaman, Afghanistan, Iran dan Turki).

Dari uraian sudut pandang ajaran Islam terkait Pengungsi, Indonesia yang mayoritas Muslim terbesar di Dunia dapat berperan penting dalam menginisiasi dan bekerja sama dengan negara OKI lainnya dalam memperbaiki dan menyelesaikan segala hal terkait pengungsi di dunia, khususnya di berada di Timur Tengah.

\section{PENUTUP}

Dari uraian di atas, dapat diambil beberapa kesimpulan bahwa sikap dan kebijakan yang ditempuh oleh negara-negara mayoritas muslim terkait dengan isu pengungsi yang berasal dari Timur Tengah, secara kuantitas (orang), mayoritas penerima pengungsi berasal dari negara OKI: Turki, Pakistan, Iran dan Lebanon. Adanya kemiripan identitas seperti aspek agama, letak geografis yang bersebelahan dan juga keterbukaan diplomasi para pemimpin negara menjadi indikator utama mereka menerima para pengungsi meskipun menuai pro-kontra di internal negara. Namun berdasarkan kuantitas banyak negara OKI yang ditampung (pengungsi), mayoritas berasal dari negara Barat: Amerika Serikat, Inggris, Perancis, Kanada dan Jerman, sehingga negara OKI lainnya dapat menjadikan contoh bagaimana mengelola pengungsi dengan baik.

Beberapa strategi kebijakan yang bisa dilakukan oleh negara-negara mayoritas muslim secara bersama untuk mengatasi isu pengungsi sudah diuraikan sebelumnya, diantaranya membuat Tim Darurat Pengungsi agar pengungsi selamat dalam perjalanan menuju negara tertentu, dan pemberian 
hak edukasi dan bekerja bagi pengungsi, sehingga dapat meningkatkan kualitas dan mandiri serta mengurangi ketergantungan dengan bantuan dalam/luar negeri. Ajaran Islam terkait penanganan pengungsi sudah banyak disinggung dalam banyak ayat, hadis maupun sejarah Islam, akan tetapi masyarakat negara Muslim jarang menyebut dan mengartikulasikan 'hijrah' ketika berurusan dengan pengungsi. Indonesia merupakan negara mayoritas Muslim terbesar di dunia dan dengan kekuatan politik luar negeri (PBB, ASEAN, G20, G15) dan ekonomi yang baik (GDP besar diantara negara OKI) dapat berperan lebih dalam upaya penanganan pengungsi, khususnya yang berada di timur tengah.

\section{DAFTAR PUSTAKA}

Al-Qur'an al-Karim

10 ways countries can help refugees integrate|World Economic Forum (2016). Available at: https://www.weforum.org/agenda/2016/05/10-wayscountries-can-help-refugees-integrate/.

8 ways to solve the world refugee crisis I Amnesty International (2020). Available at: https://www.amnesty.org/en/latest/campaigns/2015/10/eightsolutions-world-refugee-crisis / .

Adiputera, Yunizar \& Prabandari, Atin. (2018). Addressing Challenges and Identifying Opportunities for Refugee Access to Employment in Indonesia. Policy Brief. Diakses dari https://drive.google.com/file/d/1BRM_fiDabssUmuoAGfUVZTj1gohoMhTb/ view.

Ahmad, A. (1997) Social Welfare: A Basic Islamic Value.

Amnesty International. (2015). 8 Ways To Solve The World Refugee Crisis. Diakses

dari

https://www.amnesty.org/en/latest/campaigns/2015/10/eight-solutionsworld-refugee-crisis/

Amnesty International. (2016). Arab Spring: Five Years On. Diakses dari https://www.amnesty.org/en/latest/campaigns/2016/01/arab-spring-fiveyears-on/.

Asia Tenggara: Perjalanan Mematikan - Krisis Pengungsi dan Perdagangan Manusia di Asia Tenggara | Amnesty International (2015). Available at: https://www.amnesty.org/en/documents/asa21/2574/2015/id/

Breitman, R., Kraut, A. M., \& Kraut, A. M. (1987). American refugee policy and European Jewry, 1933-1945. Indiana University Press.

CNN Indonesia. (2019, Juli 6). UNHCR Akui Dana Terbatas untuk Tangani Pengungsi di Indonesia. CNN Indonesia online. Diakses dari https://www.cnnindonesia.com/nasional/20190705195855-20409590/unhcr-akui-dana-terbatas-untuk-tangani-pengungsi-di-indonesia.

Cornell, V. J. (2007) Voices of Islam: Voices of life: family, home, and society. Greenwood Publishing Group.

Corrigan, J. (2016) Jews, Christians, Muslims: A Comparative Introduction to Monotheistic Religions. Routledge.

Creswell, J. W., \& Creswell, J. D. (2017). Research design: Qualitative, quantitative, and mixed methods approaches. Sage publications. 
Dunay, A. M. (2017). The fourth wave of democratization: A comparative analysis of Tunisia and Egypt (Senior Honours Project). Diakses dari https://pdfs.semanticscholar.org/316f/f1a55aefa2b30789557ed0d63c6e9f 17335d.pdf.

Feller, E. (2001). International refugee protection 50 years on: The protection challenges of the past, present and future. International Review of the Red Cross, 83(843), 581-606.

Feller, E. (2001). The evolution of the international refugee protection regime. Washington University Journal of Law \& Policy, 5, 129.

Gillroy, J. M. (2002) The Moral Austerity of Environmental Decision Making: Sustainability, Democracy, and Normative Argument in Policy and Law. Duke University Press.

Goodwin-Gill, G. S. (2014). The international law of refugee protection. The Oxford handbook of refugee and forced migration studies, 36-47.

Hangartner, D., Dinas, E., Marbach, M., Matakos, K., \& Xefteris, D. (2019). Does exposure to the refugee crisis make natives more hostile?. American Political Science Review, 113(2), 442-455.

Hashmi, S. (2009) Islamic Political Ethics: Civil Society, Pluralism, and Conflict. Princeton University Press.

Hayatli, M. (2012). Islam, international law and the protection of refugees and IDPs. Forced Migration Review, 2.

History of The Organisation of Islamic Cooperation (OIC) (2020) Oic-oci.org. Available at: Oic-oci.org.

HRH Prince El Hassan bin Talal of Jordan. (June 2019). A lifelong commitment to justice. FMR Online. Diakses dari https://www.fmreview.org/ethics/bintalal

Jick, T.D. (1979). Mixing qualitative and quantitative methods: Triangulation in action. Administrative science quarterly, 24(4), 602-611.

Juan, E. S. (2004) Working Through the Contradictions: From Cultural Theory to Critical Practice. Bucknell University Press.

Nadig, A. (2002). Human Smuggling, National Security, and Refugee Protection. Journal of refugee studies, 15(1), 1-25.

Nicholson, F., \& Kumin, J. (2017). A guide to international refugee protection and building state asylum systems. Inter-Parliamentary Union: Geneva, Switzerland.

OIC: 40 Years of Frustrations Al Jazeera (2009). Available at: https://www.aljazeera.com/programmes/general/2009/10/200910261043 188533.html

Palmer, M. D. (2012) Religion and Social Justice. New Jersey: John Wiley \& Sons.

Pinfari, Marco. (2009). Nothing but failure? : the Arab League and the Gulf Cooperation Council as mediators in Middle Eastern conflicts. Working Paper No. 45, seri 2. Diakses dari https://assets.publishing.service.gov.uk/media/57a08b7be5274a31e0000 ba4/WP45.2.pdf .

Rahaei, S. (2012). The rights of refugee women and children in Islam. Forced Migration Review, 4.

Shoukri, A. M. (2010). Refugee status in Islam: concepts of protection in Islamic tradition and international law (Vol. 7). IB Tauris. 
South Africa: Attacks on Foreign Nationals | Human Rights Watch (2019). Available at: https://www.hrw.org/news/2019/04/15/south-africaattacks-foreign-nationals

Stefon, M. (2010) Islamic Beliefs and Practices. New York: Britannica Educational Publishing.

The Best Ways to Deal with the Refugee Crisis I International Rescue Committee (IRC) (2016). Available at: https://www.rescue.org/press-release/best-waysdeal-refugee-crisis

The World Bank. (2018). Refugee population by country or territory of origin. Diakses dari https://data.worldbank.org/indicator/SM.POP.REFG.OR?locations=XQ\&na me_desc=true.

UNHCR. (2019). Refugees. Diakses dari https://www.unhcr.org/refugees.html.

Worldwide, I. R. (2012) ISLAM AND REFUGEES. Available at: https://www.unhcr.org/afr/protection/hcdialogue 